УДК 364.27

\title{
ИННОВАЦИОННЫЙ ПОДХОД К РЕШЕНИЮ ПРОБЛЕМ СОЦИАЛЬНОЙ РЕАБИЛИТАЦИИ НЕСОВЕРШЕННОЛЕТНИХ С РАЗЛИЧНЫМИ ФОРМАМИ ОТКЛОНЯЮЩЕГОСЯ ПОВЕДЕНИЯ
}

\author{
Мартынова Татьяна Николаевна \\ к.пед.н., доцент \\ Лончакова Дарья Евгеньевна \\ ФГБОУ ВО «Кемеровский \\ государственный университет»
}

\begin{abstract}
Аннотация: В статье охарактеризованы признаки отклоняющегося поведения несовершеннолетних, проанализированы факторы возникновения данного явления, приведена типология форм отклоняющегося поведения несовершеннолетних, представлена характеристика основных проблем социальной реабилитации несовершеннолетних с отклоняющимся поведением, описана значимость инновационного подхода в решении данных проблем.
\end{abstract}

Ключевые слова: Несовершеннолетние, отклоняющееся поведение, социальная реабилитация, формы отклоняющегося поведения несовершеннолетних, проблемы несовершеннолетних, инновационный подход.

\section{INNOVATIVE APPROACH TO SOLVING PROBLEMS OF SOCIAL REHABILITATION OF MINORS WITH VARIOUS FORMS OF DEVIANT BEHAVIOR}

\section{Martynova Tatyana Nikolaevna Lonchakova Darya Evgenievna}

\begin{abstract}
The article describes the signs of deviant behavior of minors, analyzes the factors of occurrence of this phenomenon, provides a typology of forms of deviant behavior of minors, describes the main problems of social rehabilitation of minors with deviant behavior, and describes the importance of an innovative approach to solving these problems.
\end{abstract}


Key words: Minors, deviant behavior, social rehabilitation, forms of deviant behavior of minors, problems of minors, innovative approach.

На современном этапе развития российского общества происходят преобразования, затрагивающие практически все системы, в которые вовлечена личность: государство, общество, семья. Эти изменения нашли отражение в образе жизни, поведении граждан. Несмотря на позитивные перемены, выявляется ряд социальных проблем, одна из которых - отклоняющееся поведение несовершеннолетних. Одной из причин данного явления выступает дестабилизация института семьи, и, как следствие, снижение личностного потенциала несовершеннолетних, отсутствие у них ценностных и нравственных ориентиров, планов и перспектив дальнейшей жизни.

По данным Федеральной службы государственной статистики в Российской Федерации количество несовершеннолетних с расстройствами поведения в возрасте до 14 лет составило 186341 в 2015 году и 185549 в 2019 году, в возрасте 15-17 лет - 64036 в 2015 году и 65376 в 2019 году [1]. Представленные данные свидетельствуют о том, что количество несовершеннолетних с расстройствами поведения, в том числе отклоняющимся поведением, не снижается в последние годы.

Отклоняющееся поведение несовершеннолетних является социальной проблемой, так как тесно связано с проблемой социальной дезадаптации и социальной безопасности, несет угрозу деградации несовершеннолетних граждан страны. Рост исследовательского интереса к проблеме отклоняющегося поведения несовершеннолетних вызван необходимостью совершенствования подходов к социальной реабилитации и повышения ее эффективности. В Концепции развития государственной семейной политики Российской Федерации до 2025 года отмечается необходимость совершенствования существующего опыта социальной реабилитации несовершеннолетних с отклоняющимся поведением. Преодолению данной тенденции способствует инновационный подход к социальной реабилитации с данной категорией несовершеннолетних.

Разработке теории девиантного поведения посвящены работы Я.И. Гилинского, Ю.Ю. Комлева, Л.В. Макшанцевой, М.В. Зотова, Е.С. Набойченко, Н.Х. Сафиуллина, С.П. Татаровой. Типология отклоняющегося поведения, проявления и характеристики исследовалась А.Ю. Егоровым, Е.В. Змановской, 
Ю.А. Клейбергом, Н.В. Майсак, В.Д. Менделевичем, Т.В. Рыцаревой. Типология форм отклоняющегося поведения несовершеннолетних анализируется в работах Е.А. Аникудимовой, О.Б. Белых, Т.Г. Евдокимовой, У.С. Поздняковой, А.Е.Шалагина, А.К. Шалагиной и др. В исследованиях О.Б. Белых, А.В. Бурдюгиной, Ю.Н. Галагузовой, Ю.В. Лужкова, Т.А. Ерохиной, T.Е. Титовой, Г.А. Магомедова описываются инновационные формы организации социальной реабилитации несовершеннолетних с отклоняющимся поведением.

Многие исследователи подчеркивают, что именно несовершеннолетние с отклоняющимся поведением более всего подвержены высокому риску нарушения процесса социализации на различных уровнях: психологическом, биологическом, социальном [2; 3; 4; 5]. Исследователи отмечают, что отличительным признаком отклоняющегося поведения является несоответствие общепринятым нормам разной интенсивности. Именно социальная норма является отправной точкой изучения отклоняющегося поведения и сложившейся мерой допустимого поведения индивида или группы индивидов, например, несовершеннолетних [4].

Отклоняющееся поведение несовершеннолетних формируется под влиянием взаимозависимых внешних и внутренних факторов. К внешним факторам относятся процессы, происходящие в обществе - политические, экономические, институциональные, идеологические, общекультурные, социальные и т.д. [3]. Среди указанных факторов следует выделить социальные факторы, как процессы функционирования общества, которые потенциально могут обуславливать отклоняющееся поведение несовершеннолетних.

Внутренними факторами, т.е. социально-психологическими детерминантами отклоняющегося поведения несовершеннолетних, выступают личностные, индивидуальные характеристики - тревожность, эмоциональное огрубление, низкая самооценка [6, с. 116]; повышенная возбудимость, расторможенность влечений, нарушения эмоционально-волевой сферы [7, с. 24]; психическая депривация [4, с. 139].

Отклоняющееся поведение, как социальное явление, характеризуется многообразием форм, проявлений и характеристик. Анализ современных научных исследований отечественных авторов позволил нам обобщить типы и формы отклоняющегося поведения, которые наиболее часто встречаются у несовершеннолетних. При этом, при различных типах отклоняющегося 
поведения несовершеннолетних, его формы могут иметь как социальные, так и психологические проявления.

Е.А. Аникудимова в своих исследованиях описывает два типа отклоняющегося поведения несовершеннолетних: 1) отклоняющееся поведение в реальном пространстве проявляется в таких формах как правонарушения (хулиганство, воровство), аддикции (алкоголизм, наркомания, игромания), сексуальные девиации (рискованное сексуальное поведение, проституция), агрессивное поведение (аутоагрессия, суицидальное поведение, буллинг); 2) отклоняющееся поведение, реализуемое в виртуальном пространстве, например, интернет-пространстве - хакерство, кибербуллинг, диффамация (анонимное распространение по компьютерным сетям ложной информации), геймерство, интернет-зависимость, вовлеченность в виртуальные «клубы самоубийц» и т.д. [1].

Другие исследователи при анализе типов, признаков и формы отклоняющегося поведения несовершеннолетних выделяют делинквентное поведение (нарушение правовых норм); суицидальное поведение; деструктивные формы поведения - наркомания, пьянство, токсикомания, игровая зависимость или гэмблинг-зависимость (лудомания); агрессивное поведение (физическая агрессия, вербальная агрессия, косвенная агрессия), сопровождающееся различными враждебными действиями, негативизмом; аморальное поведение и т.д. [5; 8].

Различные формы отклоняющегося поведения чаще всего наблюдаются у несовершеннолетних из неблагополучных семей, находящихся в трудной жизненной ситуации и социально опасном положении. При этом специалисты учреждений социальной реабилитации для несовершеннолетних, центров социальной помощи семье и детям и других учреждений системы социальной защиты сталкиваются с нарушениями развития и школьной дезадаптацией у детей младшего школьного возраста (от 6-7 до 9-10 лет), с проявлениями девиантного и делинкветного поведения в подростковом возрасте (с 10 до15 лет) и старшем школьном возрасте (15-17 лет).

Большинство несовершеннолетних $\mathrm{c}$ отклоняющимся поведением нуждается в социальной реабилитации, которую принято рассматривать как процесс и результат, как деятельность и технологию. Социальная реабилитация несовершеннолетних с отклоняющимся поведением представляет собой систему средств и методов, направленных на восстановление социально 
одобряемого поведения несовершеннолетних, возвращение их к нормальному процессу социализации; создание условий и возможностей, гарантирующих восстановление социальных связей и функций, включение и восполнение среды жизнеобеспечения для каждого ребенка.

Процесс социальной реабилитации несовершеннолетних целесообразно организовывать с учетом форм проявления отклоняющегося поведения, что позволяет выбрать наиболее подходящие формы работы для конкретного ребенка, заменить проявления отклоняющегося поведения формами одобряемого поведения [9].

Анализ практики социальной реабилитацией несовершеннолетних с отклоняющимся поведением в реабилитационных учреждениях системы социальной защиты населения свидетельствует о необходимости совершенствования этого вида деятельности за счет использования инновационного подхода.

Инновационный подход к социальной реабилитации несовершеннолетних с отклоняющимся поведением предполагает:

- совершенствование управления реабилитационной деятельностью для достижения большей эффективности данного процесса $[10 ; 11]$;

- использование инновационных форм реабилитации (например, волонтерская деятельность, тьюторство и т.д.) [11];

- внедрение инновационных технологий и методов работы (например, арттерапевтические технологии, технологии онлайн-консультирования, информационные технологии, профориентационные методы работы и т.д.) [12];

- применение социального проектирования в практике социальнореабилитационных учреждений для несовершеннолетних [13].

Применение инновационных технологий дает возможность вести реабилитационную работу средствами, доступными и понятными для несовершеннолетних, оказывать помощь несовершеннолетним анонимно, что имеет большое значение для сохранения их психологического комфорта; способствует созданию необходимой информационно-коммуникационной среды.

Примером реализации опыта социального проектирования и инновационной практики в Кемеровской области является служба развития социальных технологий и инноваций «СОЦЛАЙН» [13]. Деятельность службы направлена на оказание поддержки детям, находящиеся в социально опасном 
положении или иной трудной жизненной ситуации, в том числе детям с отклоняющимся поведением, проходящим курс реабилитации в детских учреждениях социальной защиты Кемеровской области. Координация деятельности Службы осуществляется социально-реабилитационным центром для несовершеннолетних (ГКУ СРЦ «Маленький принц», г. Кемерово).

Служба осуществляет разработку и реализацию собственных проектов (программ) и мероприятий, способствующих эффективному внедрению инновационных технологий; внедрение инновационных моделей и технологий, направленных на достижение устойчивых, социально значимых результатов деятельности в интересах детей и их семьей, в частности технологии социальной реабилитации.

Таким образом, инновационный подход к социальной реабилитации несовершеннолетних с различными формами отклоняющегося поведения является одним из востребованных в деятельности социальнореабилитационных учреждений для детей, а также других учреждений социального обслуживания семьи и детей. Его реализация на практике позволяет обеспечить максимальное использование личностных ресурсов несовершеннолетнего с отклоняющимся поведением как субъекта социальной реабилитации для решения его проблем. Благодаря технологизации процесса социальной реабилитации несовершеннолетних с отклоняющимся поведением, использованию инновационных технологий и методов работы обеспечивается эффективность социально-реабилитационной деятельности, достигается его оптимизация, повышается результативность.

\section{Список литературы}

1. Федеральная служба государственной статистики. Раздел «Семья, материнство и детство: здравоохранение, дружественное к детям, и здоровый образ жизни». П. 3.10. Заболеваемость детей психическими расстройствами и расстройствами поведения. URL: https://www.gks.ru/folder/13807 (дата обращения: 11.12.2020).

2. Аникудимова Е. А. Современные формы проявления девиантного поведения подростков в аспекте социально-педагогической деятельности // Симбирский научный вестник. №4 (22). - Ульяновск, 2015. - С. 14-19. 
3. Рыцарева Т. В. Индивидуально-психологические особенности подростков с разными типами отклоняющегося поведения и их связь с ценностными ориентациями родителей: автореф. дис.... канд. псих. наук: 19.00.01 - Общая психология, психология личности, история психологии. - М., 2018. $-31 \mathrm{c}$.

4. Липунова О.В. Взаимосвязь дезадаптации и отклоняющегося поведения несовершеннолетних // Социальное поведение личности: оценки и стратегии. Коллективная монография. - Ульяновск, 2016. URL: https://www.elibrary.ru/item.asp?id=26171646 (дата обращения 09.12.2020).

5. Шалагина А.Е., Шалагина А.К. Типология подростков и молодежи, характеризующихся различными формами девиантного поведения // Вопросы педагогики. - M., 2020. № 4-1. - C. 289-293. URL: https://www.elibrary.ru/ item.asp?id=42700253 (дата обращения: 28.11.2020).

6. Макшанцева Л.В., Зотова М.В. К вопросу изучения внешних и внутренних факторов девиантного поведения подростков // Человеческий капитал. 2019. № 1 (121). - - C. 116-127. URL: https://www.elibrary.ru/ item.asp?id=36709889 (дата обращения: 28.11.2020).

7. Салтыкова-Волкович М. В. Причины и особенности девиантного поведения // Вестник Полоцкого государственного университета. Серия Е. Педагогические науки. - Новополоцк. 2016. № 15. - С. 24-28.

8. Позднякова У. С. Понятие, признаки и формы девиантного и делинквентного поведения детей // Университет им. В.И. Вернадского. №2(51). 2014. C. 119-126. URL: http://vernadsky.tstu.ru/pdf/2014/02/17.pdf (дата обращения 29.11.2020).

9. Евдокимова Т. Г. Современные тенденции и особенности девиантного поведения подростков (региональный аспект): автореф. дис. ... канд. соц. наук: 22.00.04 - Социальная структура, социальные институты и процессы. - Уфа, 2009. $-24 \mathrm{c}$.

10. Родермель Т. А. Особенности инновационной деятельности в учреждениях социального обслуживания. URL: https://researchjournal.org/social/osobennosti-innovacionnoj-deyatelnosti-v-uchrezhdeniyaxsocialnogo-obsluzhivaniya/ (дата обращения 09.12.2020).

11. Белых О. Б. Особенности управления социальной реабилитацией несовершеннолетних с отклоняющимся поведением: дис. ... канд. соц. наук: 22.00 .08 - социология управления. - М., 2008. - 222 с. 
12. Бурдюгина А.В. Инновационные технологии социальной работы с детьми в условиях социально-реабилитационного центра // В сборнике: Психолого-педагогическая деятельность: сферы сотрудничества и взаимодействия. Материалы $\mathrm{V}$ Межрегиональной заочной научно-практической интернет-конференции с международным участием. 2019. C. 142-146. URL: https://www.elibrary.ru/item.asp?id=42282384 (дата обращения: 11.12.2020).

13. Служба развития социальных технологий и инноваций «СОЦЛАЙН». URL: http://осознание-ко.pф/index/0-9 (дата обращения: 12.12.2020).

(C) Т.Н. Мартынова, Д.Е. Лончакова, 2020 